\title{
Traditional ecological knowledge and biodiversity management in the Andes of southern Ecuador
}

\section{Perdita Pohle, Andrés Gerique, Erlangen}

\section{Introduction}

By now it is sufficiently well understood that any attempt to preserve primary forest in the tropics is destined to fail if the interests and use claims of the local population are not taken into account. Therefore, in addition to strict protection of the forests, an integrated concept of nature conservation and sustainable land use development needs to be sought (e.g. ElLENBERG 1993). The research project of the German Research Foundation (Deutsche Forschungsgemeinschaft - DFG) presented here explores the extent to which traditional ecological knowledge and indigenous biodiversity management strategies can be made available for a long-term land use development. The project chose to use a specialized approach, namely the investigation of indigenous/ local knowledge systems as part of the ethnoecological methodology (e.g. MülLER-BöKER 1999; MÜNZEL 1987; Nazarea 1999; Posey \& Balée 1989; Warren et al. 1995). In biodiversity-rich places local people usually have a detailed ecological knowledge, for example of species, ecosystems, ecological relationships and historical or recent changes to them. Numerous case studies have shown how traditional ecological knowledge and traditional practices serve to effectively manage and conserve natural and man-made ecosystems and the biodiversity contained within (e.g. BERKES 1999; Fujisaka et al. 2000; Pohle 2004; Posey 1985; Toledo et al.1994). In ongoing interdisciplinary and integrative research projects like BIOTA AFRICA (Biodiversity Monitoring Transect Analysis in Africa, German Federal Ministry of Education and Research), STORMA INDONESIA (Stability of Rainforest Margins in Indonesia, German Research Foundation, Collaborative Research Centre 552) or within the interdisciplinary programme of the National Centre of Competence in Research North-South implemented by the Swiss National Science Foundation (SNSF), investigations on traditional ecological knowledge and biodiversity management are an integral part.

\section{The tropical mountain rainforests of southern Ecuador - a «hot spot» of biodiversity}

The tropical mountain rainforests of the eastern Andean slopes in southern Ecuador have an extraordinary rich biodiversity (BARTHLOTT et al. 1996). The area under study, the Podocarpus National Park and its surroundings, is especially noteworthy for its species diversity and belongs to one of the so-called hot spots of biodiversity worldwide (MYERS et al. 2000). The tropical mountain rainforests of southern Ecuador are of crucial importance for the preservation of genetic resources, and play an important role as an ecosystem and habitat for flora and fauna. At the same time humans have lived here and sustain themselves since centuries. However, in more recent times (since 4-5 decades), these mountain forest ecosystems, which have been described as particularly sensitive (DIE ERde 2001), have come under enormous pressure from the expansion of agricultural land - especially pastures -, the extraction of timber, the mining of minerals, the tapping of water resources and other forms of human intervention. According to Hamilron et al. (1995), 90\% of the original forest cover in the Andes can be regarded as either destroyed or altered. At present, the annual deforestation rate of $1.2 \%$ for Ecuador is the highest of all South American countries (Food and Agriculture Organization of the United Nations (FAO) 2005).

\section{Indigenous and local ethnic communities}

The northern and eastern surroundings of the Podocarpus National Park, the special areas under study, are settled by indigenous Shuar and Saraguro communities as well as Mestizo-Colonos (Fig. 1).

The Shuar area of settlement extends from the lower levels of the tropical mountain rainforest (approx. $1,400 \mathrm{~m}$ a.s.l.) down to the Amazonian lowland (Oriente) in the region bordering Peru. The Shuar, who belong to the Jívaro linguistic group (Amazonian Indians), are typical forest dwellers who practice shifting cultivation mainly in subsistence economy. Their staple crop is manioc which they plant together with taro and plantains on small rotating plots in forest gardens. They also fish, hunt and gather forest products. During the last decades some Shuar have also begun to raise cattle and some are engaged in timber extraction as well. Neither the Incas nor the Spaniards succeeded in permanently subduing the Shuar. It was only in the $20^{\text {th }}$ century that the latter started coming into frequent contact with missionaries and colonists. With the infrastructural opening of several traditional Shuar territories, the way of life and the livelihood of many Shuar have dramati- 


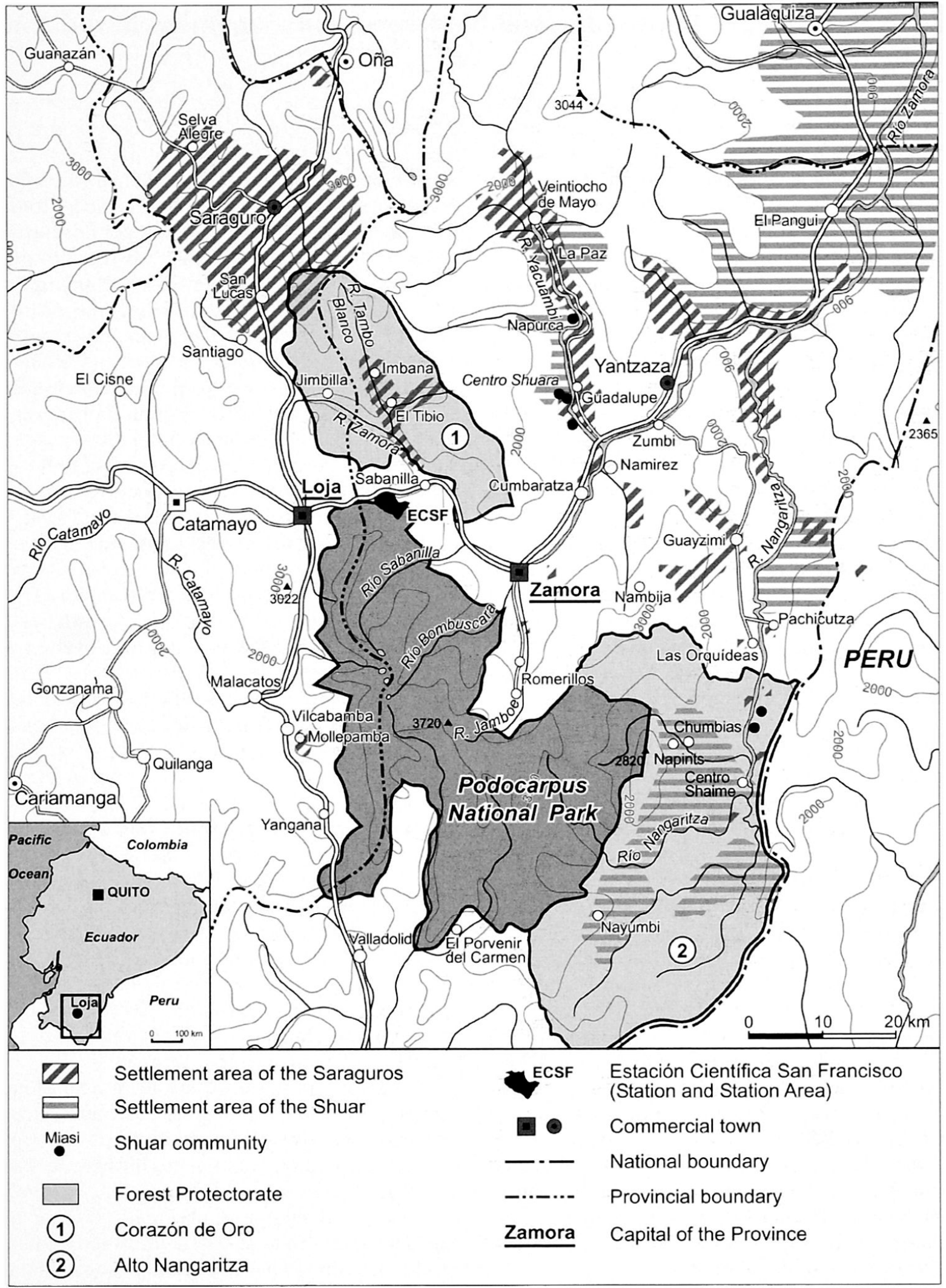

Fig. 1: Podocarpus National Park and settlement areas of indigenous groups Podocarpus Nationalpark und Siedlungsgebiete indigener Gruppen

Le Parc National de Podocarpus et les aires de peuplement des groupes indigènes

Sources: Instituto Geográfico Militar 1998: República del Ecuador 1:1,000,000; Belote 1998; Naturaleza \& Cultura Internacional 2006: Mapa No 2: Reserva de la Biosfera Podocarpus - El Condor. Zonificacion y Áreas Protegidas; own investigations PoHLE 2003-2005; draft: P. PoHLE; cartography: L. RITTER 
cally changed during the past decades (cf. RuDEL \& Horowitz 1993).

The Saraguros, highland Indians who speak Quichua, live as agro-pasturalists for the most part in the temperate mid-altitudes $(1,800-2,800 \mathrm{~m}$ a.s.l. $)$ of the Andes (Sierra) in southern Ecuador. It is assumed that they originally came from the Titicaca region in Bolivia and were resettled as workers and vassals in the Andean highlands by the Incas during their almost 70 -year rule (A.D. 1463-1531) in southern Ecuador (BELOTE 1998). As early as the $19^{\text {th }}$ century, the Saraguros kept cattle to supplement their traditional system of mixed cultivation, featuring maize, beans, potatoes and other tubers (GRÄF 1990). Now, cattle ranching has developed as the main branch of their economy. A shortage of pasture land arose at the beginning of the $20^{\text {th }}$ century, forcing the Saraguros to expand their pasturage not only into the mist forest and páramo levels, but also particularly far into the tropical forests of the Oriente, which soon became their permanent area of settlement. Like other indigenous groups of Ecuador, the Saraguros have undergone cultural change: most Saraguros are today Catholic Christians who hardly speak any Quichua outside their main area of settlement, but only Spanish, and increasingly seek out job opportunities away from agriculture.

Even though the traditional forms of life and livelihood, both of the Shuars and the Saraguros, have greatly changed under the pressure of external influences (e.g. missionary activities, agrarian colonization), both indigenous groups have been able to preserve core areas of their traditional culture, including an extensive specialized knowledge of their environment, along with numerous life-support strategies through natural resource management.

In the North and East of Podocarpus National Park Mestizo-Colonos are the most dominant ethnic group in numbers. They are colonists of mestizo ethnicity, who have come to the area during the last $4-5$ decades to log timber, and to practise cattle farming and agriculture. In Latin America the term mestizo is generally used to indicate people of mixed Spanish and indigenous descent. Most of the Mestizo-Colonos are said to have come from poor peasant families of the Sierra of Loja province. Their migration was especially encouraged by the national land reform of 1964, which opened to poor peasants the possibility of becoming landowners by clearing and transforming forest into pastures and fields. A severe drought in 1968 in Loja province (VAN DEN EYNDEN 2004) boosted this colonization process. Additionally, the colonization was facilitated by the construction of the Loja-Zamora road (1962) connecting the Andean and Amazonian areas.

\section{Aims and methods of the ethnoecological research project}

The research project was carried out within the DFGResearch Unit FOR 402: «Functionality in a Tropical Mountain Rainforest: Diversity, Dynamic Processes and Utilization Potentials under Ecosystem Perspectives» (www.bergregenwald.de). During 2004, 2005 and 2006 ethnoecological, especially ethnobotanical, and agrogeographical research was undertaken in sample communities of the Shuar (Shaime, Napints, Chumbias), the Saraguros (El Tibio) and the MestizoColonos (Sabanilla). The goal was:

- to document the indigenous and local knowledge of traditionally utilized wild and cultivated plants (the ethnobotanical inventory was undertaken committing the «Code of Ethics»),

- to analyze current forms of land use including the cultivation of forest and home gardens, and

- to evaluate ethno-specific life-support strategies as well as strategies for natural resource management.

\section{The significance of plant use for the Shuar, Saraguros and Mestizo-Colonos}

The Shuar of the Nangaritza valley have a comprehensive knowledge of plants and their utilization. All households make extensive use of forest products. According to the ethnobotanical survey, the actual inventory of traditionally used wild plants of the Shuar includes 211 species. Most of the wild plants are used to supplement the diet (74). Given the lack of state health care, medicinal plants also assume great significance (63). Many plants, too, are used as construction material (67), as tools and for handicrafts (37), as fuel, fodder or as ritual plants. The Shuar use forest products exclusively for their own needs, there is virtually no commercialization.

The Saraguros from El Tibio have a far less comprehensive knowledge of wild plant species and their utilization. The actual ethnobotanical inventory includes only 73 wild plant species. Most of them are ruderal plants used as medicine (38) or plants used for their wood (17). As agro-pasturalists, they have converted most of the primary forest into pastures, home gardens and fields, leaving forest remains only along mountain ridges or in river ravines. Their actual plant knowledge reflects this traditional way of life. They have a comprehensive knowledge of cultivated plants (103), mainly pasture and crop plant species - even more than the Shuar (86) - but they are less familiar with forest plant species. The latter knowledge is mainly reduced to woody varieties which they extract and sell before clearing the forest. 
The Mestizo-Colonos of the surrounding areas of Sabanilla base their economy on cattle ranching. They have converted large areas of forests into pastures. As settlers from the western and most arid area of Loja Province they seem to not be familiarized with the local flora and hence make only little use of it. The actual ethnobotanical inventory - although not completed yet - includes a total of only 58 wild plant species. Timber is the main forest product (20), while some ruderal plants and the fruit of a few tolerated tree species are used as food (12) or as medicine (6). On the other hand, the Mestizo-Colonos cultivate 54 different species for food and 35 species for medicinal purposes and have a comprehensive knowledge of pasture species.

\section{Agrobiodiversity in the Shuar's and Saraguros' tropical home gardens (huertas)}

The tropical home gardens of indigenous and local communities are generally regarded as places of great agrobiodiversity and refuges of genetic resources (Watson \& Eyzaguirre 2002). Furthermore, they contribute significantly to securing and diversifying food supplies. This applies wholly to Shuars' and Saraguros' gardens, which feature a large number of both wild and cultivated species, and which play their part in providing subsistence needs. Staple crops, such as maize, tubers and beans, may be cultivated primarily in chacras (fields), but home gardens (huertas) have an essential role to play in supplementing the diet with fruits and vegetables, furnishing households with medicinal plants and spices, and fodder and timber.

The forest gardens of the Shuar are characterized by an especially great diversity of species and breeds. In five huertas studied (size: approx. $600-1,000 \mathrm{~m}^{2}$ ), a total of 185 wild and cultivated plant species and breeds were registered. For the most part they serve as nutritional items $(58 \%)$ or medicines $(22 \%)$. The main products cultivated are starchy tubers like manioc (Manihot esculenta) and taro (Colocasia esculenta), along with various breeds of plantains (Musa sp.). Moreover, the planting of a large number of traditional local breeds was documented: e.g. 29 breeds of manioc and 21 breeds of Musa sp. - a further indication of the crucial significance that home gardens have for the in situ conservation of botanical genetic resources (MÜNZEL 1989: 434).

The huertas of the Saraguros likewise display a great diversity of useful plants. In one sample home garden studied in El Tibio, 51 species of cultivated plants were identified. In total 95 cultivated plants were registered among the Saraguros of El Tibio. Again, the majority are plants that supply nutritional value $(41 \%)$, fol- lowed by medicinal and ornamental plants (each 20\%). The most important cultivated products are plantains, tubers and various types of fruit. Given their relatively dense and tall stands of trees, the multi-tiered arrangement of plants and the great diversity of species, the gardens of the Saraguros can be seen as an optimal form of exploitation in the region of tropical mountain rainforests.

\section{Indigenous concepts of biodiversity management - their contribution to a sustainable land use development}

If the hypothesis is accepted that a multi-facetted economic and cultural interest in the forest on the part of indigenous and local communities offers effective protection against destruction, then a key role must be assigned to the analysis and evaluation of the ethnospecific knowledge about tropical mountain rainforests and their potential uses. Both indigenous groups have developed natural resource management strategies that could be used and expanded, in line with the concept "preservation through use», for future biodiversity management, but this should be done only in an ethno-specific way.

The Shuars' traditional way of managing biodiversity is based on a sense of being closely bound culturally, spiritually and economically to the forest. The sustainability of their form of land use has long since been put to the test (MüNZEL 1977, 1987). As traditional forestdwellers, sustainable elements of biodiversity management can be found in (Photo 1):

- their regulated practice of shifting cultivation, which - given the correspondingly long time for regeneration - is thought to conserve the soil and the vegetation. The system of cultivation and fallow on small rotating plots (Fig. 2) has much in common with ecological succession in that it uses the successional process to restore the soil and the vegetation after use for farming (KRICHER 1997: 179). In the Shuar forest gardens, the fallow periods last for about 24-30 years while the cultivation periods covers four years;

- their tending of forest gardens according to principles of agroforestry and mixed cropping with a high agrobiodiversity and a particular high breed variety of cultivated plants. As it is commonly known, polycultures are more resistant to insect attacks and plant diseases;

- the natural fertilization of soils by mulching and the use of digging sticks and dibbles as a suitable form of cultivating the soil, and finally

- their sustainable use of a broad spectrum of wild plants in small quantities satisfying only subsistence needs and avoiding over-harvesting. 


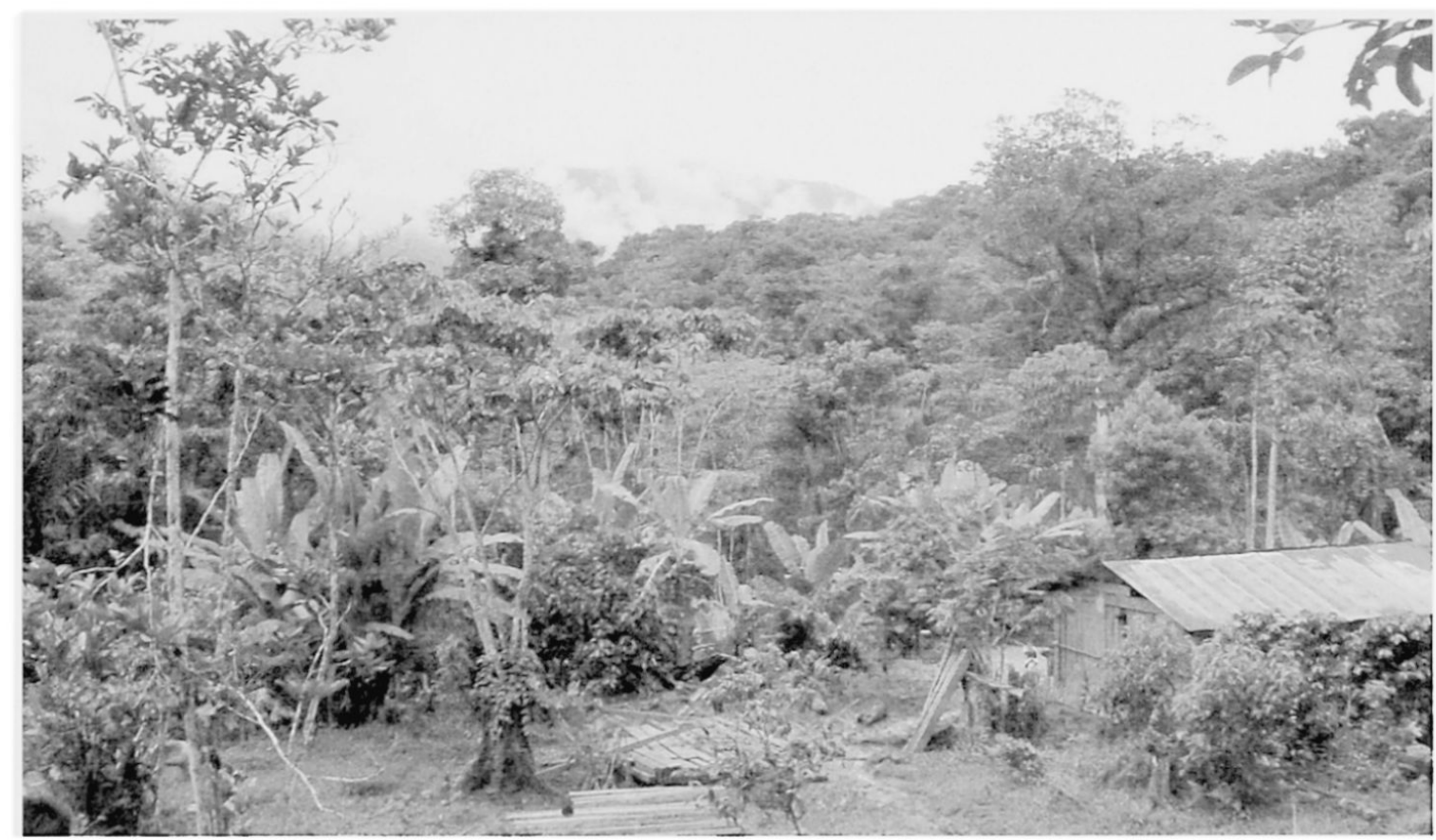

Photo 1: Napints $(1,000 \mathrm{~m})$ : scattered settlement of the Shuar in the tropical rainforest at the eastern periphery of the Podocarpus National Park

Napints (1000 m): Shuar Streusiedlung im tropischen Regenwald am östlichen Rand des Podocarpus Nationalparks

Napints (1000 m): peuplement dispersé des Shuar dans la forêt tropicale à l'est du Parc National de Podocarpus

Photo: A. Gerique

If the Shuars' traditionally practiced and clearly sustainable plant biodiversity management is to be preserved, then this is possible only by the following preconditions: the legalization of their territorial claims and, along with that, a comprehensive protection of their territories by demarcating reservations for example. This appears to be underway with the establishment of a so-called Reserva Shuar (NeILl 2005). Additionally, it is necessary to respect and support the Shuars' cultural identity, not only to avoid the loss of traditional environmental knowledge, in particular traditional plant lore. To improve livelihood in an economic sense, additional sources of financial income are essential. In this line, promotion of ecotourism, support of traditional handicrafts, and the cultivation of useful plants for a regional market could be discussed.

While the Shuars' forest management can be evaluated as preserving plant biodiversity, the sustainability of the Saraguros' use of the environment has yet to be rated. Market-oriented stockbreeding has particularly led in recent decades to the rapid increase of pastures at the expense of forest. In spite of ecological conditions unfavorable to agricultural pursuits (steep V-shaped valleys, acidic soils, extremely high precipita- tion), these Andean mountain farmers have at least, by means of their intensive form of pasture management, succeeded in generating a sufficiently stable agrarian and cultural landscape (Photo 2). In contrast to many completely deforested and ecologically devastated areas settled by Mestizo-Colonos (Photo 3), the richly chequered agrarian landscape of the Saraguros presents, not only aesthetically but also ecologically, a fundamentally more positive picture.

Among the Saraguros, initial attempts to manage biodiversity in line with the concept "preservation through use» can also be elaborated. The first thing to be mentioned in this context is the keeping of home gardens with a wide spectrum of wild and cultivated plants, particularly woody species. With regard to the diversity of species, the remnants of forest still largely preserved in ecologically unfavourable locations are significant. In order to stem the further loss of biodiversity, however, it will be necessary to convince the Saraguros that in particular, scrub and wasteland (matorral) should be replanted with native tree species. The pressure on the tropical mountain rainforests caused by the pasturing economy will only be reduced, though, when the Saraguros can be shown a profitable 


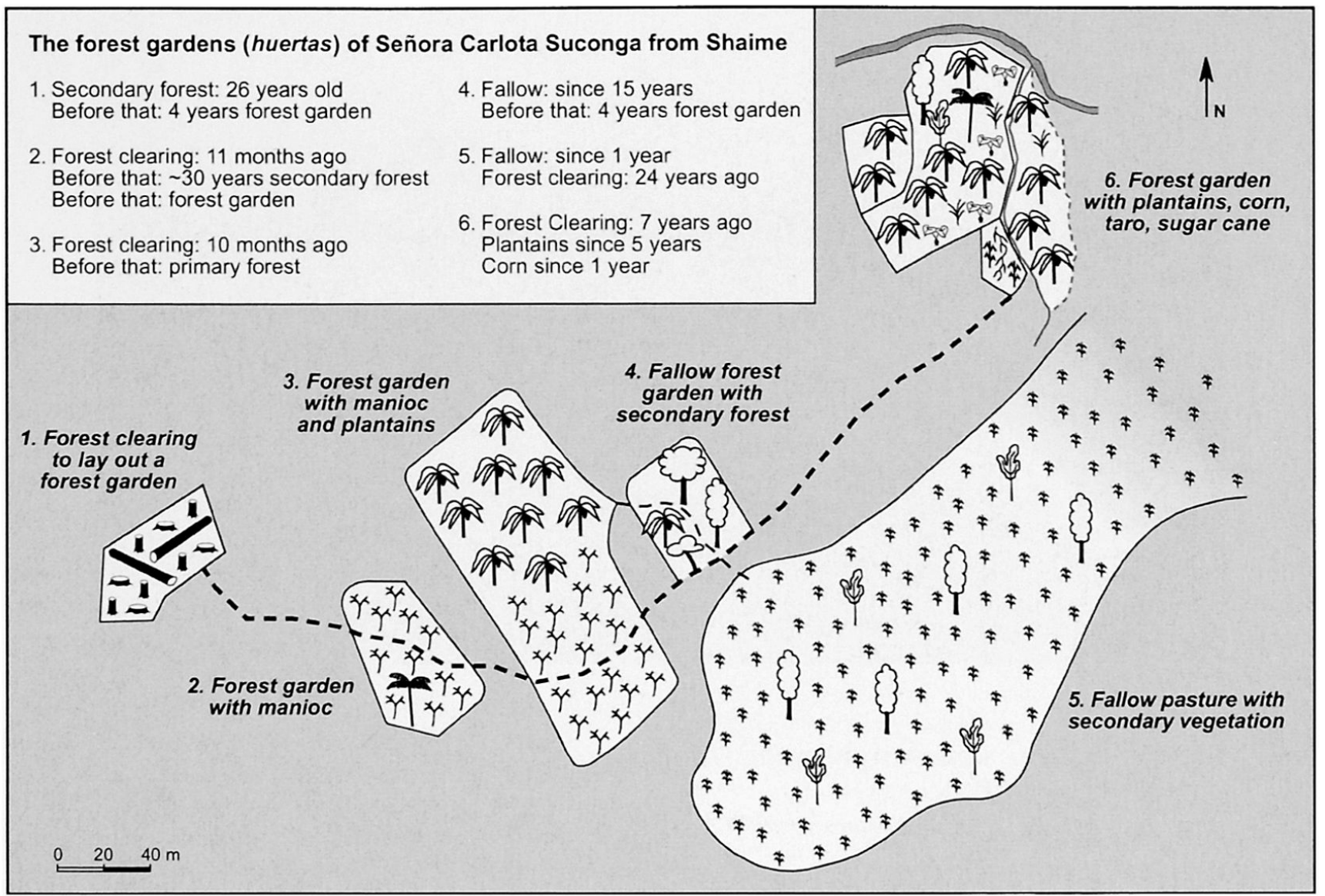

Fig. 2: The forest gardens (huertas) of Señora Carlota Suconga from Shaime (920 m)

Waldgärten ("huertas») von Señora Carlota Suconga aus Shaime (920 m)

Les jardins forestiers ("huertas») de Señora Carlota Suconga à Shaime (920 m)

Source: Field survey October 2004; draft: P. Pohle, E. TAPIA, A. GeriQue; cartography: L. RitTer

alternative to it. As examples of promising endeavours in this context may be regarded:

- the selective timber production and replanting with native tree species as it is proposed by foresters (GüNTER et al. 2003),

- the introduction of silvipastoral or agroforestry systems,

- market-oriented gardening,

- the cultivation and marketing of useful plants, e.g. medicinal herbs,

- the promotion of «off-farm» employment opportunities, and

- the payment for environmental services to protect the watershed area of Loja.

\section{The overexploitation of natural resources by the Mestizo-Colonos}

The Mestizo-Colonos living today in the northern buffer zone of the Podocarpus National Park arrived from the 1960s onwards, encouraged by the national land reform of 1964. Most of the Mestizo-Colonos settling along the road between Loja and Zamora arrived only during the last 25 years. As colonizers they converted large areas of tropical mountain rainforests into almost treeless pastures (Photo 3). To sustain their livelihood they were forced to use even very steep and marginal areas for cattle ranching. Fire was the most common way of clearing the forests to gain pasture land. During the late 1970s and in the 1980s, cattle ranching was displaced as main regional economic activity by timber extraction. This provoked the selective disappearance of many tree species with economic value and the alteration of adjacent forest areas, but as WUNDER (1996) pointed out, the need of new pasture land and not the extraction of timber was the principal reason for deforestation in this area. At present, the economy of the Mestizo-Colonos is again based on cattle ranching. Since forest remains are nowadays more far away from the housings and good quality timber is getting scarce in the forests, the 


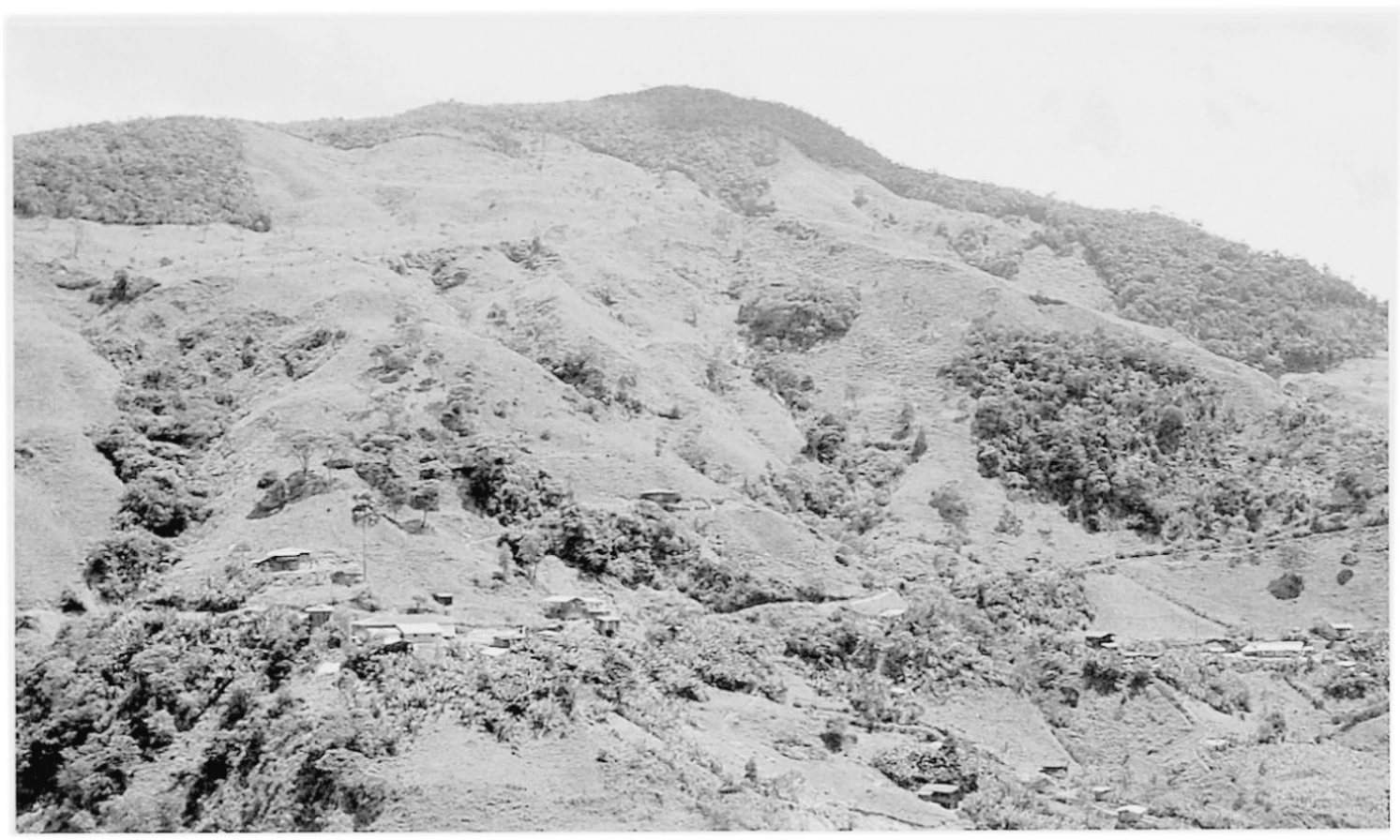

Photo 2: Richly chequered cultural landscape of the Saraguros on a steep slope of the Rio Tibio valley with the scattered settlement of El Tibio (1,770 m)

Reich gegliederte Agrarlandschaft der Saraguro an einer steilen Talflanke des Rio Tibio mit der Streusiedlung El Tibio $(1770 \mathrm{~m})$

Un riche paysage agricole des Saraguro sur un flanc de la vallée abrupte du Rio Tibio avec le peuplement dispersé d'El Tibio $(1770 \mathrm{~m})$

Photo: P. POHLE

Mestizo-Colonos are becoming more receptive to the idea of tolerating a variety of tree species in order to have shadow for cattle, timber for repairing fences, fuel, or material for construction. Tabebuia chrysantha, Cedrela spp., Piptocoma discolor, Inga spp. and Psydium guayava are among the most common tolerated species.

Among the Mestizo-Colonos, the low profitability of the extensive form of cattle ranching has lead to a high in- and out-migration and a correspondingly high fluctuation in landownership and possession. To avoid poverty, most of them have an alternative income, e.g. from small shops near the road, or a second occupation as day labourers. As a consequence, in marginal areas pasture management is obviously neglected, mainly because of the limited availability of labour. Compared to the indigenous ethnic groups, the Mestizo-Colonos are much more heterogeneous. Extreme overexploitation is especially typical for newcomers and colonizers of the first generation mainly living in scattered fincas along the road between Loja and Zamora. In contrast, colonizers of the second or third generation living in village communities like in the upper Rio
Zamora valley have developed a more adapted and sustainable form of land use, in many respects similar to that of the Saraguros.

To avoid a further loss of biodiversity and to reduce the pressure on the tropical mountain rainforests caused by cattle ranching profitable alternatives have to be offered. Similar measures as those presented above for the Saraguros are necessary: e.g. timber production in form of reforestation with native tree species, market-oriented gardening, cultivation of medicinal herbs, payments for environmental services. These measures should also take into account an improvement of the carrying capacity of existing pastures by introducing legumes (Leguminosae) and other fodder plants, the improvement of the cattle breeds and of the veterinary services. In any case, measures to stop the loss of biodiversity in the area should take into account the difficult economic situation of most of the Mestizo-Colonos households. The prohibition of using fire and the establishment of protected areas have surely reduced the deforestation rate, but such measures do not face the real causes of deforestation and have increased the animosity against conservation. 


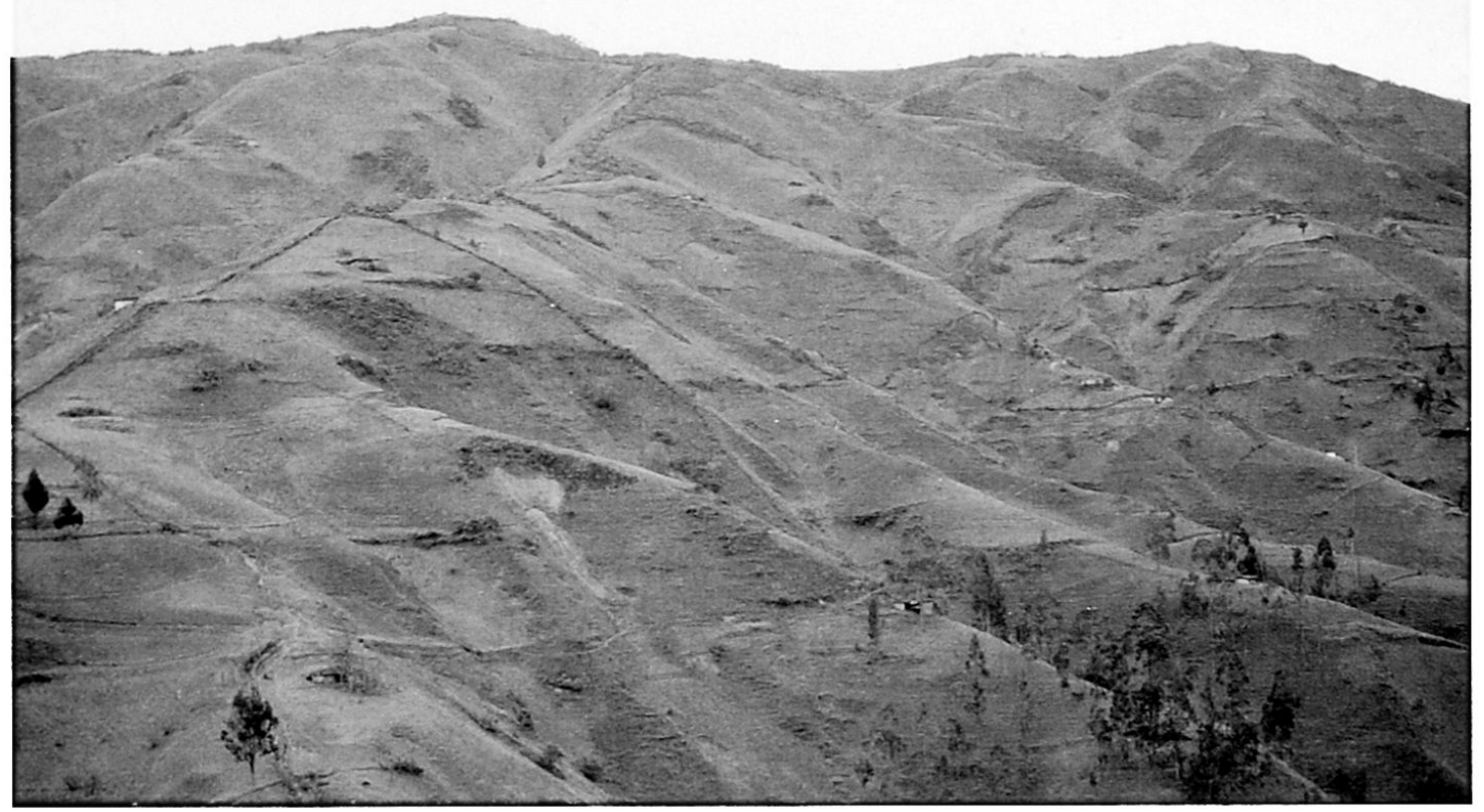

Photo 3: Deforested and overused agrarian landscape of the Mestizo-Colonos north of Loja

Entwaldete und übernutzte Agrarlandschaft der Mestizo-Colonos nördlich von Loja

Un paysage agricole déboisé et surexploité des Mestizo-Colonos au nord de Loja

Photo: P. POHLE

\section{Protecting biological diversity - from National Park to Biosphere Reserve}

The Podocarpus National Park, covering a total of 146,280 ha, was established in 1982 as southern Ecuador's first conservation area, with the goal of protecting one of the country's last intact mountain rainforest ecosystems, one particularly rich in species and largely untouched by humans. The creation of a national park in the middle of a fairly densely populated mountain region necessarily gave rise to numerous conflicts of interest and use rights, e.g. agrarian colonization, illegal timber extraction, conflicts about landownership and possession, mining activities, tourism.

The experience in international nature conservation during the past decades has shown that resource management, if it is to be sustainable, must serve the goals of both nature conservation and the use claims of the local population. The strategy is one of «protection by use» instead of «protection from use», a concept that has emerged throughout the tropics under the philosophy «use it or lose it» (JANZEN 1992, 1994). In the following, strategies are presented that show a way how people can benefit from the national park without degrading the area ecologically: the implementation of extractive reserves, the promotion of ecotourism and as the most promising approach the establishment of a Biosphere Reserve.
Given the high biodiversity of tropical rainforests and the fact that indigenous people in general have a comprehensive knowledge of forest plants and their utilization, it seems possible according to KrICHER (1997: $357)$ to view the rainforest as a renewable, sustainable resource from which various useful products can be extracted on a continuous basis. In view of the high number of plant species that are currently collected by extractivists in the surrounding of the Podocarpus National Park (e.g. the Shuar) the preservation of large areas of rainforest would make economic sense as well as serve the interests of conservation and preservation of biodiversity. Thus, the establishment of an extractive reserve could be suggested as an alternative to deforestation.

In line with the concept "protection by use» ecotourism can be structured such that it is compatible with conservation interests and serves the local economy as well. This is also the experience around Podocarpus National Park. The attraction of the park is clearly the tropical rainforest with its specific wildlife, particularly tropical birds, less visitors have botanical or eco-geographical interests. However, compared to other national parks of South America, e.g. the Manu National Park of Peru, southern Ecuador and the Podocarpus National Park is not a major tourist destination. 
The most promising approach, in which conservational protection and sustainable development are the guiding principles, is the integrated concept of conservation and development exemplified by UNESCO's Biosphere Reserve (UNESCO 1984). The idea behind it is to mark out representative sections of the landscape composed of, on the one hand, natural ecosystems (core area) and, on the other, areas that bear the impress of human activity (buffer and development zone) (ERDMANN 1996). In Ecuador, three biosphere reserves have already been drawn up (Ministerio DEL AMBIENTE 2003). The establishment of such a reserve would also be desirable for southern Ecuador, and has been recently submitted for approval. Alongside a strictly protected core area comprising Podocarpus National Park, it might encompass in a buffer zone cultural landscapes that have arisen historically (e.g. Vilcabamba) together with sanctuaries of indigenous communities (e.g. the proposed Reserva Shuar) and, in a development zone, areas of recent agrarian colonization.

Biosphere reserves are strongly rooted in cultural contexts and traditional ways of life, land use practices and local knowledge and know-how. In the buffer and development zone of the Podocarpus National Park measures to be taken could rely on the rich ethno-specific traditions in forest and land use practices by indigenous and local communities. In a first step, it would be desirable to develop with the participation of the local communities environmental management plans. On the one hand, they could support the ethno-specific cultural tradition and strengthen the social identity of local communities. On the other hand, these plans should comprise regulations for hunting, fishing, timber and plant harvesting, exclusion of human-created fires but also for house and road construction. In southern Ecuador management plans are still in various phases of discussion and implementation. However, there is still a big gap between vision and reality. An intensive discussion about the participation of the population and of local non-governmental organizations (NGOs) about the assignment of environment competence to the regional-local administration was started. But, the realization of concepts like "cooperative management structure» could not consolidate and find political acknowledgement. According to GallRAPP (2005) it failed to create effective platforms for participation and negotiation, to build up a common vision of the participating persons and to create a social awareness in order to implement new structures.

\section{Bibliography}

Barthlott, W., Lauer, W. \& A. Placke (1996): Global distribution of species diversity in vascular plants. Towards a world map of phytodiversity. - In: Erdkunde 50, 4:317-327.
Belote, J.D. (1998): Los Saraguros del sur del Ecuador. - Quito: Ediciones Abya-Yala.

BERKES, F. (1999): Sacred ecology. Traditional ecological knowledge and resource management. - Philadelphia: Taylor \& Francis.

Die ERDE (2001): Themenheft «Tropische Wald-Ökosysteme». - Die Erde 132, 1.

ElLENBERG, L. (1993): Naturschutz und technische Zusammenarbeit. - In: Geographische Rundschau 45, 5: 290-300.

ERdMANN, K.-H. (1996): Der Beitrag der Biosphärenreservate zu Schutz, Pflege und Entwicklung von Natur- und Kulturlandschaften in Deutschland. - In: Kastenholz, H.G., ERdmann, K.-H. \& M. WolfF (Hrsg.): Nachhaltige Entwicklung. Zukunftschancen für Mensch und Umwelt. - Berlin: Springer.

Food and Agriculture Organization of the United NATIONS (FAO) (2005): State of the world's forests 2005. - Rome: FAO.

Fujisaka, S., Escobar, G. \& E.J. Veneklaas (2000): Weedy fields and forests. Interactions between land use and the composition of plant communities in the Peruvian Amazon. - In: Agriculture, ecosystems and environment 78: 175-186.

GallRAPP, D. (2005): Naturschutz im Wandel? Vision und Realität integrativer Naturschutzkonzepte am Beispiel des Podocarpus-Nationalparks in Südecuador. - In:Tübinger geographische Studien 142: 417-441.

GRÄF, M. (1990): Endogener und gelenkter Kulturwandel in ausgewählten indianischen Gemeinden des Hochlandes von Ecuador. - München: tuduv Verlagsgesellschaft.

Günter, S., Stimm, B. \& M. Weber (2003): Silvicultural contributions towards sustainable management and conservation of forest genetic resourcec in southern Ecuador. - In: Proceedings of the $2^{\text {nd }}$ Congress «Conservation of the biodiversity in the Andes and the Amazon region", Loja, 25 th to $30^{\text {th }}$ of August 2003.

Hamilton, L., Juvik, J. \& F. Scatena (1995): The Puerto Rico tropical cloud forest symposium. Introduction and workshop synthesis. - In: Ecological studies 110: $1-19$.

JANZEN, D.H. (1992): A south-north perspective on science in the management, use and economic development of biodiversity. - In: SandLund, O.T., Hindar, K. \& A.H.D. Brown (eds): Conservation of biodiversity for sustainable development. - Oslo: Scandinavian University Press: 27-52.

JANZEN, D.H. (1994): Wildland biodiversity management in the tropics. Where are we now and where are we going? - In: Vida silvestre neotropical 3: 3-15.

KRICHER, J. (1997): A neotropical companion. An introduction to the animals, plants and ecosystems of the new world tropics. $-2^{\text {nd }}$ edition, Princeton, N.J.: Princeton University Press.

Ministerio del Ambiente (2003): Ponencias del Ministerio del Ambiente para el fortalecimiento y 
consolidación del sistema nacional de áreas protegidas. Primer congreso nacional de áreas naturales protegidas. - Quito: Ministerio del Ambiente.

MÜller-BöKer, U. (1999): The Chitawan Tharus in southern Nepal. An ethnoecological approach. - = Nepal Research Centre publications 21, Stuttgart: Steiner.

MüNZEL, M. (1977): Jívaro-Indianer in Südamerika. Roter Faden zur Ausstellung 4. - Frankfurt am Main: Museum für Völkerkunde.

MüNZEL, M. (1987): Kulturökologie, Ethnoökologie und Ethnodesarrollo im Amazonasgebiet. Zur Differenzierung ökologischer Indianerforschung. - = Entwicklungsperspektiven 29, Kassel: LateinamerikaDokumentationsstelle, Gesamthochschule Kassel.

MÜNZEL, M. (1989): Bemerkungen zum indianischen Umweltbewußtsein im Amazonasgebiet. - In: Geographische Rundschau 41, 7-8: 431-435.

Myers, N., Mitrermeier, R.A., Mittermeier, C.G., Da FonsecA, G.A.B. \& J. Kent (2000): Biodiversity hotspots for conservation priorities. - In: Nature 403: 853-858.

Nazarea, V.D. (ed.) (1999): Ethnoecology, situated knowledge/located lives. - Tucson, Arizona: The University of Arizona Press.

Neill, D. (2005): Cordillera del Cóndor. Botanical treasures between the Andes and the Amazon. - In: Plant talk 41: 17-21.

PoHLE, P. (2004): Erhaltung von Biodiversität in den Anden Südecuadors. - In: Geographische Rundschau 56, 3: 14-21.

PoSEY, D.A. (1985): Indigenous management of tropical forest ecosystems. The case of the Kayapó indians of the Brazialian Amazon. - In: Agroforestry systems 3: 139-158.

Posey, D.A. \& W. BAlÉE (eds.) (1989): Resource management in Amazonia. Indigenous and folk strategies. - = Advances in economic botany 7, Bronx, N.Y.: New York Botanical Garden.

Rudel, T.K. \& W. Horowitz (1993): Tropical deforestation. Small farmers and land clearing in the Ecuadorian Amazon. - New York: Columbia University Press.

Toledo, V.M., Ortiz, B. \& S. Medellín-Morales (1994): Biodiversity islands in a sea of pasturelands. Indigenous resource management in the humid tropics of Mexico. - In: Etnoecologica 2, 3: 37-50.

UNESCO (ed.) (1984): Action plan for biosphere reserves. - In: Nature and resources 20, 4: 11-22.

VAN DEN EYNDEN, V. (2004): Use and management of edible non-crop plants in southern Ecuador. - PhD thesis in Applied Biological Sciences, Gent University, Belgium.

Warren, D.M., Slikkerveer, L.J. \& G. Brokensha (eds) (1995): The cultural dimension of development. Indigenous knowledge systems. - London: Intermediate Technology Publications.
WATSON, J.W. \& P.B. EyzaguiRRE (2002): Home gardens and in situ conservation of plant genetic resources in farming systems. - Proceedings of the $2^{\text {nd }}$ International Home Gardens Workshop, $17^{\text {th }}$ to $19^{\text {th }}$ of July 2001, Witzenhausen, Germany.

www.bergregenwald.de 13.11.2006.

WUNDER, S. (1996): Deforestation and the uses of wood in the Ecuadorian Andes. - In: Mountain research and development 16, 4: 367-382.

\section{Abstract: Traditional ecological knowledge and biodiversity management in the Andes of southern Ecuador}

The tropical mountain rainforests of the eastern Andean slopes in southern Ecuador have an extraordinary rich biodiversity. At the same time, these sensitive ecosystems are vulnerable because of the extension of agricultural land, the extraction of timber, mining activities, the tapping of water resources and similar anthropogenic intrusions. Ethno-specific knowledge of the tropical rainforest ecosystem was determined in sample communities of the Shuar, the Saraguros and the Mestizo-Colonos - particularly with respect to the natural forest resources and their uses. Ethnoecological and agrogeographical research methods were used to document the indigenous knowledge of traditionally utilized wild and cultivated plants, to analyze current forms of land use (including the traditional cultivation of forest and home gardens), and to evaluate ethno-specific survival strategies and strategies of biodiversity management.

\section{Zusammenfassung: Traditionelles Umweltwissen und Biodiversitätsmanagement in den Anden Südecuadors}

Die tropischen Bergregenwälder der östlichen Andenausläufer sind durch eine überproportional hohe Biodiversität gekennzeichnet. Gleichzeitig stehen diese, vielfach als besonders sensibel beschriebenen Bergwaldökosysteme unter einem enormen Nutzungsdruck durch die Ausdehnung landwirtschaftlicher Nutzflächen, durch Holzentnahme, Abbau von Bodenschätzen, Wassergewinnung und andere anthropogene Eingriffe. Ethnospezifische Kenntnisse über das Ökosystem «tropischer Bergregenwald», insbesondere über die natürlichen Waldressourcen und deren Nutzungsmöglichkeiten wurden in exemplarischen Gemeinden der Shuar, der Saraguro und der Mestizo-Colonos erhoben. Unter Anwendung ethnoökologischer und agrargeographischer Forschungsmethoden wurden die indigenen Kenntnisse über traditionell verwendete Wild- und Kulturpflanzen dokumentiert, aktuelle Formen der Landnutzung einschließlich des traditionellen Anbaus in den Wald- und Hausgärten analysiert sowie die ethnospezifischen Lebensunterhaltsstrategien und Strategien des Biodiversitätsmanagements bewertet. 
Résumé: Savoir écologique traditionnel et gestion de la biodiversité dans les Andes du sud de l'Equateur

Les forêts tropicales montagnardes du contrefort est des Andes sont marquées par une biodiversité exceptionnelle. En même temps, celles-ci sont décrites comme des écosystèmes particulièrement fragiles, souffrant de la surexploitation due à l'expansion des surfaces agricoles par prélèvement de bois, extraction de ressources minérales, prélèvements hydrauliques et autres interventions anthropiques. Des données ethnospécifiques relatives à l'écosystème des forêts montagnardes tropicales ont été collectées dans des communes caractéristiques des Shuar, des Saraguro et des Mestizo-Colonos, particulièrement en ce qui concerne les ressources naturelles de la forêt et leurs possibilités d'exploitation. Les connaissances de la population indigène relatives aux plantes sauvages et aux cultures ont fait l'objet d'une attention particulière, grâce à des méthodes de recherches ethnoécologiques et de géographie rurale. Les formes actuelles de l'exploitation du sol, y compris la culture traditionnelle dans les jardins potagers et forestiers, ont également été étudiées. Finalement, les stratégies ethnospécifiques de subsistance ainsi que les stratégies de gestion de la biodiversité ont été évaluées.

Prof. Dr. Perdita Pohle, Dipl.-Ing. Andrés Gerique, Institute of Geography, Friedrich-Alexander-University of Erlangen-Nürnberg, Kochstrasse 4/4, D-91054 Erlangen, Germany.

e-mail:

ppohle@geographie.uni-erlangen.de

agerique@geographie.uni-erlangen.de

Manuskripteingang/received/manuscrit entré le 12.5.2006

Annahme zum Druck/accepted for publication/accepté pour l'impression: 3.12 .2006 